\title{
Skin Resident Memory T Cells May Play Critical Role in Delayed-Type Drug Hypersensitivity Reactions
}

\author{
Elisa Maria Schunkert, Pranali Nitin Shah and Sherrie Jill Divito* \\ Department of Dermatology, Brigham \& Women's Hospital, Harvard Medical School, Boston, MA, United States
}

Delayed-type drug hypersensitivity reactions (dtDHR) are immune-mediated reactions with skin and visceral manifestations ranging from mild to severe. Clinical care is negatively impacted by a limited understanding of disease pathogenesis. Though $T$ cells are believed to orchestrate disease, the type of $T$ cell and the location and mechanism of $T$ cell activation remain unknown. Resident memory $T$ cells $\left(T_{\mathrm{RM}}\right)$ are a unique $T$ cell population potentially well situated to act as key mediators in disease pathogenesis, but significant obstacles to defining, identifying, and testing $T_{R M}$ in dtDHR preclude definitive conclusions

OPEN ACCESS

Edited by:

Jason Trubiano,

University of Melbourne, Australia

Reviewed by:

Philippe Saas,

U1098 Interactions Hôte-GreffonTumeur \& Ingénierie Cellulaire et Génique (INSERM), France Wen-Hung Chung, Chang Gung Memorial Hospital,

Taiwan

${ }^{*}$ Correspondence: Sherrie Jill Divito sdivito@bwh.harvard.edu

Specialty section:

This article was submitted to Alloimmunity and Transplantation,

a section of the journal

Frontiers in Immunology

Received: 15 January 2021 Accepted: 06 August 2021 Published: 23 August 2021

Citation: Schunkert EM, Shah PN and Divito SJ (2021) Skin Resident Memory T Cells May Play Critical Role in Delayed-Type Drug Hypersensitivity Reactions.

Front. Immunol. 12:654190. doi: 10.3389/fimmu.2021.654190 at this time. Deeper mechanistic interrogation to address these unanswered questions is necessary, as involvement of $\mathrm{T}_{\mathrm{RM}}$ in disease has significant implications for prediction, diagnosis, and treatment of disease.

\begin{abstract}
Keywords: adverse drug reactions, delayed-type drug hypersensitivity reactions, fixed drug eruption, maculopapular exanthem, drug reaction with eosinophil and systemic symptoms, Stevens-Johnson syndrome, tissue-resident memory T cells, toxic epidermal necrolysis
\end{abstract}

\section{INTRODUCTION}

Delayed-type drug hypersensitivity reactions (dtDHR) are a significant public health problem with potential for high morbidity and mortality and considerable cost to healthcare systems (1-5). Skin is the most commonly affected organ with severity ranging from a mild exanthem (maculopapular drug eruption, MPE), to life-threatening blistering and sloughing of skin (Stevens-Johnson syndrome/toxic epidermal necrolysis, SJS/TEN), with potential for significant visceral involvement (drug reaction with eosinophilia and systemic symptoms, DRESS). The pathobiology of dtDHR remains poorly understood, impeding prediction and prevention, diagnosis, identification of culprit drug, and effective treatment. DtDHR are immune-mediated adverse drug reactions that typically appear days to weeks after drug exposure (3). The timing of onset combined with epidemiological, histopathological and laboratory data incriminate $\mathrm{T}$ cells as primary drivers of disease, however, the type of pathogenic $\mathrm{T}$ cell and the location and mechanism of its activation are unknown. Tissue-resident memory $\mathrm{T}$ cells $\left(\mathrm{T}_{\mathrm{RM}}\right)$ are an increasingly appreciated unique population of $\mathrm{T}$ cells that persist long-term in peripheral tissues including skin $(6,7)$. Critical roles for skin $\mathrm{T}_{\mathrm{RM}}$ in cutaneous health and several inflammatory skin diseases have been identified $(6,8)$, raising the question of whether skin $\mathrm{T}_{\mathrm{RM}}$ contribute to or cause dtDHR. This mini-review aims to provide the reader with a clearer understanding of these enigmatic cells, evidence supporting skin $\mathrm{T}_{\mathrm{RM}}$ involvement in dtDHR pathogenesis, and current barriers limiting investigation in this field. 


\section{AN OVERVIEW OF SKIN T RM BIOLOGY}

\section{T Cell Classification and Identification}

$\mathrm{T}$ cell classification is increasingly complex due to significant heterogeneity within $\mathrm{T}$ cell compartments and lack of consensus on nomenclature. Differences between mouse and human contribute further to confusion. This review therefore focuses on the most salient features required to understand skin $\mathrm{T}_{\mathrm{RM}}$ in the context of dtDHR.

Mature $\mathrm{T}$ cells are broadly classified into naïve, effector, and memory subsets. When a naïve $\mathrm{T}$ cell is stimulated with cognate antigen, changes in surface expression of multiple proteins occur that are easily assayed by flow cytometry. In both humans and mice, cell surface expression of CD44 is increased, thereby differentiating naïve $\mathrm{T}$ cells $\left(\mathrm{CD} 44^{\text {low }}\right)$ from effector and memory $\mathrm{T}$ cells $\left(\mathrm{CD} 44^{\text {high }}\right)(9,10)$. Additionally, activated $\mathrm{T}$ cells decrease surface expression of CD62L (L-selectin) and the chemokine receptor CCR7, and transiently up-regulate CD69 (1114). In addition to these phenotypic changes, $\mathrm{T}$ cell proliferation, migration to the site of inflammation, and acquisition of effector function occur, ultimately resulting in resolution of the antigenic insult $(14,15)$. Once resolved, the effector phase of the response concludes with $\mathrm{T}$ cell contraction. However, a small population of antigen-specific memory $\mathrm{T}$ cells survive that are capable of responding faster and more robustly upon re-exposure to their cognate antigen (14-16). In humans, different isoforms of CD45 expressed on $\mathrm{T}$ cells are generally helpful in distinguishing naïve $\mathrm{T}$ cells, CD45RA ${ }^{+}$, from memory $\mathrm{T}$ cells, which are typically $\mathrm{CD}^{2} \mathrm{RO}^{+}$(17).

Memory $\mathrm{T}$ cells were previously classified into two major subsets: central $\left(\mathrm{T}_{\mathrm{CM}}\right)$ and effector $\left(\mathrm{T}_{\mathrm{EM}}\right)$ memory $\mathrm{T}$ cells (18). $\mathrm{T}_{\mathrm{CM}}$ reside predominantly in secondary lymphoid organs due to their surface expression of CCR7 and CD62L and carry a high proliferative capacity upon antigen re-exposure, but lack the ability to rapidly produce effector molecules (18). Comparatively, $\mathrm{T}_{\mathrm{EM}}$ lack CCR7 and have low CD62L expression allowing them to circulate throughout the body during steady-state (18). In keeping with their role as circulating sentinels, they are capable of rapid effector function (18). More recently, $\mathrm{T}_{\mathrm{RM}}$ have been appreciated as a unique memory $\mathrm{T}$ cell population playing key roles in health and disease. $\mathrm{T}_{\mathrm{RM}}$ persist in robust numbers longterm in peripheral tissues despite absence of inflammation. Barrier sites including skin, gut, liver, lung, and mucosa are the main tissues containing large numbers of $\mathrm{T}_{\mathrm{RM}}$ (19-24), presumably due to the constant barrage of these tissues with environmental antigens. Phenotypically, $\mathrm{T}_{\mathrm{RM}}$ have low/absent expression of CD62L and CCR7 $(16,22)$, which helps prevent migration to secondary lymphoid organs $(25,26)$, and low expression of the transcription factor KLF2 and the protein S1P1 while maintaining surface expression of CD69, which further facilitates retention in peripheral tissue (27-30).

Skin $\mathrm{T}_{\mathrm{RM}}$ consist of both $\mathrm{CD}^{+}$and $\mathrm{CD}^{+}$type $\mathrm{T}$ cells, each with variable phenotype and distribution throughout skin. A subset of epidermal CD $4^{+}$and $\mathrm{CD}^{+} \mathrm{T}_{\mathrm{RM}}$ express CD103, the $\alpha_{\mathrm{E}}$ subunit of $\alpha_{\mathrm{E}} \beta_{7}$ integrin, which helps anchor $\mathrm{T}_{\mathrm{RM}}$ to epithelial cells expressing E-cadherin (29-32). The majority of $\mathrm{T}_{\mathrm{RM}}$ in healthy human skin reside in the dermis and are phenotypically
$\mathrm{CD}^{+} \mathrm{CD}^{-103^{-}}$(29). Skin $\mathrm{T}_{\mathrm{RM}}$ commonly express on their surface the skin homing molecule cutaneous lymphocyte antigen (CLA) (22) and variably the chemokine receptors CCR4, CCR6, CCR8, CCR10, and CXCR6 $(22,33-37)$. Taken together, $\mathrm{T}_{\mathrm{RM}}$ are overall best phenotypically identified in healthy human skin as $\mathrm{CD}^{+}$, $\mathrm{CD}^{+}$or $\mathrm{CD}^{+}, \mathrm{CD}_{4} \mathrm{RO}^{+} \mathrm{CD} 69^{+} \mathrm{CLA}^{+} \mathrm{CCR} 7 \mathrm{CD}^{-} 2 \mathrm{~L}^{\text {low }}$ and either $\mathrm{CD}_{103^{+}}$or $\mathrm{CD} 103^{-}$.

\section{$\mathbf{T}_{\mathrm{RM}}$ Maintain Skin Health}

$\mathrm{T}_{\mathrm{RM}}$ play an important role in immunity. Protective skin $\mathrm{T}_{\mathrm{RM}}$ can be generated in mice by immunizing with vaccinia virus $(38,39)$ or HSV $(40,41)$, and these $\mathrm{T}_{\mathrm{RM}}$ clear pathogens faster and more effectively than, or even in the absence of, circulating $\mathrm{T}$ cells (38-41). Skin $\mathrm{T}_{\mathrm{RM}}$ in humans likewise appear to effectively prevent cutaneous infection in the absence of circulating $\mathrm{T}$ cells, as patients depleted of circulating $\mathrm{T}$ cells by alemtuzumab, an anti-CD52 antibody, do not experience increased rates of infection (42). $\mathrm{T}_{\mathrm{RM}}$ provide surveillance by actively patrolling skin $(43,44)$ and are capable of rapid and potent pro-inflammatory cytokine release (29), though data suggest that rapid cytotoxicity may be constrained by PD-1 signaling (45). Surface expression of the integrin CD49a reportedly denotes functionality of skin $\mathrm{T}_{\mathrm{RM}}$, with $\mathrm{CD}^{+} \mathrm{CD} 49 \mathrm{a}^{+} \mathrm{T}_{\mathrm{RM}}$ capable of IFN $\gamma$ production and cytotoxicity, while $\mathrm{CD}^{+} \mathrm{CD} 49 \mathrm{a}^{-} \mathrm{T}_{\mathrm{RM}}$ are polarized toward IL-17 production $(46,47)$. Notably, localized skin infection generates $T_{R M}$ not only at the site of infection but potentially at distant skin sites as well, particularly in the setting of repeat inoculation $(39,48,49)$. Repeated exposure to a diversity of microbes could therefore generate an army of sentinel antigen-specific $\mathrm{T}$ cells across the expanse of skin, poised to rapidly defend against infection.

\section{Skin $\mathrm{T}_{\mathrm{RM}}$ Are Instrumental in Several Inflammatory Skin Diseases}

Increasing data support skin $\mathrm{T}_{\mathrm{RM}}$ as potentially causal or contributory to acute and chronic inflammatory skin conditions. In atopic dermatitis and psoriasis, T Cell Receptor (TCR) sequencing identified that pathogenic $\mathrm{T}$ cell clones persisted in skin at the site of resolved lesions supporting their classification as skin $\mathrm{T}_{\mathrm{RM}}(50,51)$. $\mathrm{T}$ cells remaining in resolved psoriatic lesional skin retained the propensity to produce psoriasis-inducing cytokines, explaining predisposition to disease recurrence at the same skin location after treatment discontinuation $(51,52)$, and pathogenic $\mathrm{T}_{\mathrm{RM}}$ residing in nonlesional skin from psoriasis patients are capable of eliciting a psoriasiform reaction when stimulated ex vivo (53).

Moreover, human studies suggest a role for skin $\mathrm{T}_{\mathrm{RM}}$ in acute graft-versus-host disease (GVHD), as skin T cells were shown to survive robust chemotherapy \pm total body irradiation and were present and activated during acute skin GVHD (54). Findings were complemented by a humanized mouse model showing that human skin $\mathrm{T}_{\mathrm{RM}}$ could mediate a GVHD-like dermatitis in the absence of donor $\mathrm{T}$ cells (54). These findings have direct implications for dtDHR, as acute skin GVHD clinically and histologically mirrors MPE in mild form and SJS/TEN in severe form.

Finally, skin $\mathrm{T}_{\mathrm{RM}}$ have been directly implicated in allergic contact dermatitis (ACD), another form of cutaneous delayed- 
type hypersensitivity reaction. In an ACD mouse model, increased allergen dose and number of exposures resulted in increased frequency of epidermal $\mathrm{CD}^{+} \mathrm{T}_{\mathrm{RM}}$ and worsened disease (55), and skin $\mathrm{T}_{\mathrm{RM}}$ were observed to mediate allergic reactions upon allergen re-exposure in the absence of circulating $\mathrm{T}$ cells $(49,56)$. Allergen exposure induced antigen-specific $\mathrm{T}_{\mathrm{RM}}$ locally and at distant skin sites, and concurrently antigen-specific $\mathrm{T}_{\mathrm{CM}}$ in draining and distant lymph node, all bearing identical TCR, indicating that the newly generated memory $\mathrm{T}$ cells derived from a common clone (49). Interestingly, disease was exacerbated by checkpoint inhibitor antagonists which stimulated $\mathrm{T}_{\mathrm{RM}}$ effector function, intimating that checkpoint inhibitors do constrain the $\mathrm{T}_{\mathrm{RM}}$ response (56).

\section{DO $T_{\text {RM MEDIATE DTDHR? }}$}

\section{T Cells in dtDHR}

Ample evidence implicates $\mathrm{T}$ cell mediation of $\mathrm{dtDHR}$. $\mathrm{T}$ cell infiltrate and pro-inflammatory molecules commonly attributed to effector $\mathrm{T}$ cells are observed within biopsies or blister fluid from affected skin $(57,58)$. Additionally, drug-specific $\mathrm{T}$ cells from peripheral blood have been identified by clonality studies, and in some diseased patients $\mathrm{T}$ cells from peripheral blood respond to drug in lymphocyte stimulation tests $(59,60)$. Moreover, several HLA associations have been identified that predispose patients to specific drug reactions (61-63). Prominent examples include HLA*B57:01 which predisposes patients taking the drug abacavir to DRESS (64), and HLA*B15:02 which predisposes patients to SJS/TEN if administered carbamazepine (65). T cell effector functions in $\mathrm{dtDHR}$ are increasingly appreciated, particularly in SJS/TEN, as $\mathrm{CD}^{+} \mathrm{T}$ cell produced cytotoxic granules and soluble granulysin are thought to mediate keratinocyte death $(58,66)$. Comparatively, MPE is largely considered $\mathrm{CD}^{+} \mathrm{T}$ cell/cytokine driven. Contradictory findings have been observed in DRESS, with some research supporting Th2 polarization, while other studies have observed cytotoxic $\mathrm{CD}^{+} \mathrm{T}$ cells and IFN $\gamma$ and TNF $\alpha$ signatures (66). Despite significant advancements in the above areas of research, the type of T cell mediating disease (effector, central $v s$ effector $v s$ resident memory) and the location and mechanism by which $\mathrm{T}$ cells are stimulated against drug remains largely unknown.

\section{Evidence Supporting a Role for $T_{R M}$ in dtDHR}

Studies directly investigating $\mathrm{T}_{\mathrm{RM}}$ in $\mathrm{dtDHR}$ are sparse, though there is increasing circumstantial evidence suggesting that skin $\mathrm{T}_{\mathrm{RM}}$ may be critical players in disease. Anecdotally, patients with few circulating lymphocytes secondary to chemotherapy are capable of developing dtDHRs. Iriki et al. reported a case of SJS/TEN in a patient with severe lymphopenia secondary to chemotherapy. They demonstrated by immunofluorescence microscopy of affected skin the presence of $\mathrm{CD}_{4} 5 \mathrm{RO}^{+} \mathrm{CD}^{+} 9^{+}$ $\mathrm{CD}^{+}$and $\mathrm{CD} 8^{+} \mathrm{T}$ cells despite the lack of circulating T cells (67). The presumption is that disease resulted from skin $\mathrm{T}_{\mathrm{RM}}$ that survived chemotherapy, while naïve and central and effector memory $\mathrm{T}$ cells were depleted by the treatment. However, the possibility that a low number of T cells survived chemotherapy in secondary lymphoid organs and were recruited to skin to mediate disease has not been ruled out.

A recent publication by Trubiano et al. investigated skin $\mathrm{T}_{\mathrm{RM}}$ in patients with MPE and DRESS (68). The study reported increased number of $\mathrm{CD} 45 \mathrm{RO}^{+} \mathrm{CD} 9^{+} \mathrm{CD}^{+}$and $\mathrm{CD}^{+} \mathrm{T}$ cells in skin after resolution of DRESS in one patient. In addition, the authors performed a localized drug challenge by intradermally injecting culprit drug into skin of patients with history of MPE or DRESS. Skin biopsies performed acutely after challenge during active localized inflammation and again 8 weeks after resolution demonstrated accumulation of $\mathrm{CD} 45 \mathrm{RO}^{+} \mathrm{CD}_{6}{ }^{+} \mathrm{CD} 103^{+} \mathrm{CD} 4{ }^{+}$ and $\mathrm{CD}^{+} \mathrm{T}$ cells at the 8 -week time point. The increased frequency of cells with this phenotype supports that skin $\mathrm{T}_{\mathrm{RM}}$ are generated by systemic disease and localized drug exposure (68). Similarly, patch testing suspected culprit drug in some cases induces skin inflammation in patients with history of dtDHR, affirming that drug-specific memory $\mathrm{T}$ cells are present in skin after disease resolution. For example, patch testing against abacavir has high sensitivity in patients with history of DRESS who express HLA-B`57:01 (69). Comparatively, drug naïve HLA-B ${ }^{\star 57: 01}$ positive patients were demonstrated to have circulating abacavir-reactive $\mathrm{T}$ cells yet patch test negative, reinforcing the idea that drug exposure induces skin $\mathrm{T}_{\mathrm{RM}}(70)$. Of note though, patch testing reportedly has low sensitivity for $\mathrm{dtDHR}$ reactions (71-73), raising the question of whether skin $\mathrm{T}_{\mathrm{RM}}$ accumulation is dependent on type of $\mathrm{dtDHR}$, culprit drug, and/or presence of specific HLA alleles, or alternatively low sensitivity may be secondary to a technical issue for example suboptimal drug concentration or vehicle applied during testing.

Lastly and perhaps most intriguingly, the idea that $\mathrm{T}_{\mathrm{RM}^{-}}$ mediated immunity is restrained by immune checkpoint signaling further bolsters the link between skin $\mathrm{T}_{\mathrm{RM}}$ and dtDHR (56). The coinhibitory molecules CTLA-4 and PD-1 have been linked to hypersensitivity reactions from multiple drugs in both human and animal studies (74). Clinically, immune checkpoint inhibitors (ICI) can induce dtDHR-like reactions, most notably an SJS/TEN-like phenomenon $(75,76)$. It is currently unknown whether these reactions develop due to ICI-provoked loss of tolerance to a concurrently administered drug or bystander activation in the setting of a robust anti-tumor $\mathrm{T}$ cell response. Further investigation of these reactions has substantial potential to illuminate pathobiology of dtDHR.

\section{The Curious Case of Fixed Drug Eruptions}

Perhaps the best case for skin $\mathrm{T}_{\mathrm{RM}}$ mediating at least one form of $\mathrm{dtDHR}$ is that of fixed drug eruption (FDE). Remarkably, FDE lesions reappear at the exact same skin site upon re-exposure to causative drug. Studies in resolved FDE lesions in human skin showed that intraepidermal $\mathrm{CD}^{+} \mathrm{T}$ cells constitutively expressed CD69 in the absence of inflammation, and upon drug challenge produced IFN $\gamma$ (77). Though these findings are consistent with skin $\mathrm{T}_{\mathrm{RM}}$, these $\mathrm{T}$ cells expressed primarily $\mathrm{CD}_{45 \mathrm{RA}^{+}}$rather than $\mathrm{CD}_{45 \mathrm{RO}^{+}}$(77). A separate unique subset of memory $\mathrm{T}$ cells termed $\mathrm{T}_{\text {emra }}$ can express CD45RA rather than $\operatorname{CD} 45 \mathrm{RO}(18,78,79)$, but in this study, the intraepidermal $\mathrm{CD}^{+} \mathrm{T}$ cells lacked CD57, a marker suggestive 
of $\mathrm{T}_{\text {emra }}$. This peculiar finding is yet to be resolved but highlights the phenotypic heterogeneity of memory $\mathrm{T}$ cell populations and a major challenge to accurately identifying $\mathrm{T}_{\mathrm{RM}}$.

\section{INSIGHT INTO POTENTIAL MECHANISMS OF DRUG-REACTIVE T CELL STIMULATION}

The fact that only a subset of patients expressing a predisposing HLA allele develop dtDHR upon exposure to the associated drug (80) suggests that a second " $\mathrm{X}$ " factor is necessary for disease. Evidence supports that viral infection or reactivation, particularly with herpes family viruses (HHV6, HHV7, EBV, CMV), may be this "X" factor (80-83). Presumably, the viral infection provides costimulation necessary to break $\mathrm{T}$ cell tolerance to drug (Figure 1A). In this scenario, drug-reactive naïve $\mathrm{T}$ cells could be primed in skin draining lymph nodes by dendritic cells activated by virally induced inflammation, the drug-reactive effector $\mathrm{T}$ cells migrate to skin and mediate disease as a primary immune response, then after contraction, a population of drug-reactive $\mathrm{T}_{\mathrm{RM}}$ remain in skin, capable of mediating a reaction upon drug re-exposure. Though most research has focused on infection/reactivation of herpes family viruses in the context of DRESS, similar observations have been made in MPE, the classic example being ampicillin-induced MPE in the context of EBV mononucleosis (84), and in two publications in SJS/TEN (one reporting HHV6 reactivation and one EBV reactivation) $(85,86)$. Another potential " $X$ " factor could be increased drug levels secondary to altered drug metabolism or reduced drug clearance. For example, data demonstrate that reduced renal function predisposes to allopurinol-induced severe $\operatorname{dtDHR}(87,88)$.

Alternatively, virus-specific skin $\mathrm{T}_{\mathrm{RM}}$ generated in response to a previous viral infection could potentially cross-react to drug/ drug altered peptide repertoire presented by self-MHC expressed on skin antigen presenting cells or keratinocytes (80) (Figure 1B). In support of this, activated $\mathrm{CD} 8^{+} \mathrm{T}$ cells mediating cutaneous and visceral symptoms of DRESS were shown to be EBV reactive (81), and $\mathrm{HIV}$-specific memory $\mathrm{T}$ cell clones were demonstrated to react in vitro against abacavir-altered peptide repertoire presented in the context of HLA-B ${ }^{\star 57: 01}$ (89) Whether cross-reactivity is causal to dtDHR other than DRESS remains to be elucidated.

Either scenario may help explain the link between skin $T_{R M}$ and dtDHR with systemic manifestations. Research supports that cutaneous viral infection and $\mathrm{ACD}$ can generate clonal $\mathrm{T}_{\mathrm{RM}}$ and $\mathrm{T}_{\mathrm{CM}}$ simultaneously in local and distant skin and secondary lymphoid organs $(39,48,49)$ and potentially antigen-specific $\mathrm{T}_{\mathrm{RM}}$ in other tissues as well (90). In support of this concept, identical pathogenic clones were identified in blood, skin, liver, and lung of one patient with DRESS and blood, skin, and liver in a second patient (81).

Moreover, either above scenario could account for development of dtDHR upon first exposure to a drug. Lucas et al. demonstrated that drug naïve, HLA-B ${ }^{\star} 57: 01$ positive patients contained both naïve and memory T cells in circulation capable of responding to abacavir upon in vitro stimulation (91). Presumably, rapid development of DRESS upon first drug exposure reflects mediation by cross-reactive memory $\mathrm{T}$ cells, while slower onset points toward priming of a primary drug-specific immune response. Whether this phenomenon occurs in other types of $\mathrm{dtDHR}$ remains unknown.

\section{LIMITATIONS TO THE STUDY OF SKIN $T_{\text {RM IN dtDHR }}$}

Several barriers impede the study of skin $\mathrm{T}_{\mathrm{RM}}$ in dtDHR. First, many studies rely on limited phenotypic analysis by flow cytometry or tissue immunostaining to identify skin $\mathrm{T}_{\mathrm{RM}}$. Flow cytometry commonly requires digestion and disaggregation of skin by chemical and/or physical measures resulting in loss of spatial information and potential alteration of surface marker expression (92-94). Standard tissue immunostaining overcomes these barriers but is limited to co-staining of maximum 3 antigens, and some antigens are difficult to reliably stain in formalin-fixed tissue. Further, because no single marker or combination of markers defines all skin $\mathrm{T}_{\mathrm{RM}}$, cursory phenotypic analysis can be misleading. This is especially true during active inflammation, as CD69 can be expressed by other activated T cell populations, and as

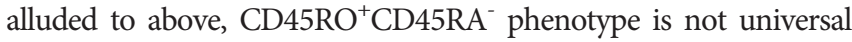
for all memory $\mathrm{T}$ cells $(18,78,79,95)$. More perplexing, the definition that $\mathrm{T}_{\mathrm{RM}}$ remain resident in peripheral tissue without recirculating has been called into question. Klicznik et al. reported that $\mathrm{CD} 4^{+} \mathrm{CD} 69^{+} \mathrm{CD} 103^{+} \mathrm{T}_{\mathrm{RM}}$ are capable of downregulating the tissue-retention marker CD69 and entering circulation (96). Moreover, elegant work by Buggert et al., transforms the current construct of memory $\mathrm{T}$ cell classification with observations that well-differentiated cytolytic memory $\mathrm{CD}^{+} \mathrm{T}$ cells remain in intravascular circulation under steady-state conditions, while less differentiated non-cytolytic non-resident memory $\mathrm{CD}^{+} \mathrm{T}$ cells recirculate between lymphoid and non-lymphoid tissues such as liver and gut (97). Whether these findings apply to skin $T_{R M}$ in steady-state or during dtDHR is unknown, though one can imagine that preferential maintenance of less differentiated non-cytolytic $\mathrm{T}$ cells rather than cytolytic T cells in tissue could be a potential means of preventing bystander tissue damage.

A second major barrier is that researchers have limited ability to investigate the immunologic events preceding clinical manifestations of dtDHR due to either lack of predictability or that it may be unsafe to (re)expose a patient to drug in the event that a reaction is predictable. Prospective studies of active disease can be equally challenging particularly for rarer forms of $\mathrm{dtDHR}$ and for severe forms that may require rapid initiation of treatment prior to sampling. This type of clinical scenario is where mouse models become essential. Historically, dtDHR research has been hampered by the lack of mouse models that meaningfully recapitulate disease, but recent advances have been achieved by administering drug to mice transgenically expressing predisposing HLA alleles $(98,99)$. Though generation of, or 
A

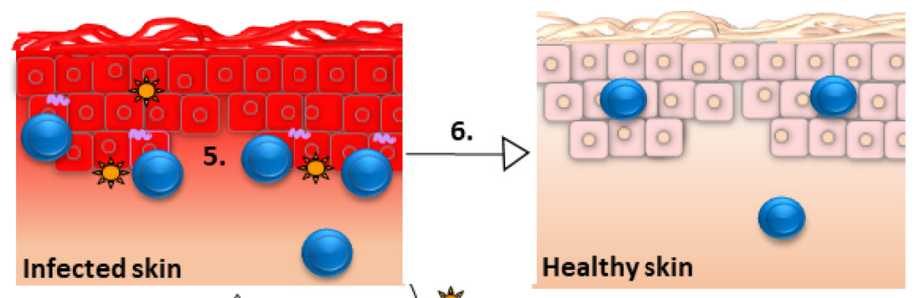

4.

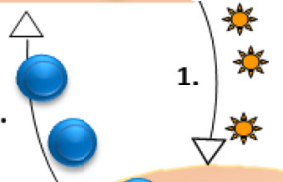

3.
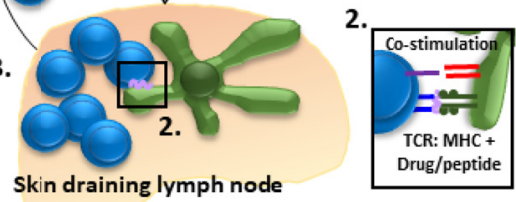

B

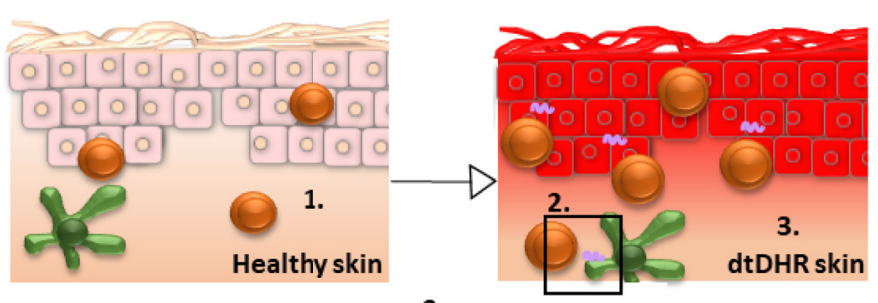

2.

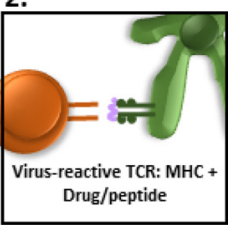

Drug-reactive T cell

Virus-reactive $T_{R M}$

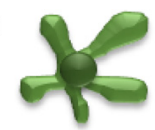

Dendritic cell

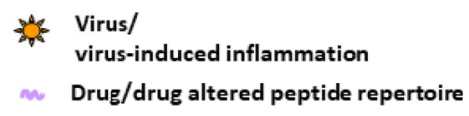

FIGURE 1 | Possible mechanisms by which drug-reactive $T_{\text {RM }}$ could be generated in skin. (A) Drug/drug altered peptide repertoire is presented to drug-reactive T cells and concurrent viral infection/reactivation provides sufficient co-stimulation to break T cell tolerance to drug: 1. Inflammatory mediators secondary to infection stimulate dendritic cells. 2. Activated dendritic cells in skin draining lymph nodes present drug/drug altered peptide repertoire to naïve drug-reactive $T$ cells and provide ample co-stimulation resulting in T cell priming. 3. Primed T cells proliferate and differentiate into effector cells, 4. migrate to skin, and 5. mediate damage as a primary immune response. 6 . Despite resolution of inflammation, drug-reactive $T_{R M}$ remain in skin, poised to mediate repeat dtDHR upon re-exposure to drug. Alternatively, factors other than viral infection, for example altered drug metabolism or reduced clearance, could potentially lead to T cell activation (not shown). (B) Drug-reactive T cells are cross-reactive to viral epitopes: 1. Virus-specific $T_{R M}$ accumulate in skin as a consequence of prior infection. 2. These virus-reactive T cells are capable of recognizing (cross-reacting to) drug/drug altered peptide repertoire presented by MHC on the surface of skin dendritic cells, macrophages and/or keratinocytes resulting in $T_{R M}$ stimulation. 3. The stimulated $T_{R M}$ produce pro-inflammatory molecules inducing DRESS, or potentially other dtDHR.

mediation by, skin $\mathrm{T}_{\mathrm{RM}}$ has not yet been tested in these mice, these models provide for the first time a platform allowing for deeper mechanistic interrogation of $\mathrm{T}_{\mathrm{RM}}$ in disease.

\section{CONCLUSIONS}

A contribution from skin $\mathrm{T}_{\mathrm{RM}}$ in dtDHR pathogenesis is an intriguing possibility with potential to shed light on a number of unanswered questions in the field. From a basic immunology perspective, it would address not only which $\mathrm{T}$ cells mediate disease but would also provide insight into mechanism(s) of $\mathrm{T}$ cell activation against drug. From a clinical perspective, it could aid predictability and diagnosis, allow for development of novel strategies to identify culprit drug, and provide insight into alternative approaches to treatment. Despite current obstacles to the study of $\mathrm{T}_{\mathrm{RM}}$ in $\mathrm{dtDHR}$, there is an increasingly strong framework in place and clearly a clinical need to justify further investigation. 


\section{AUTHOR CONTRIBUTIONS}

ES prepared the manuscript with assistance from PS. SD supervised the project and oversaw the authoring and revision of the manuscript. All authors contributed to the article and approved the submitted version.

\section{REFERENCES}

1. Hsu DY, Brieva J, Silverberg NB, Silverberg JI. Morbidity and Mortality of Stevens-Johnson Syndrome and Toxic Epidermal Necrolysis in United States Adults. J Invest Dermatol (2016) 136(7):1387-97. doi: 10.1016/j.jid.2016.03.023

2. Velasco-Tirado V, Alonso-Sardon M, Cosano-Quero A, Romero-Alegria A, Sanchez-Los Arcos L, Lopez-Bernus A, et al. Life-Threatening Dermatoses: Stevens-Johnson Syndrome and Toxic Epidermal Necrolysis. Impact on the Spanish Public Health System (2010-2015). PloS One (2018) 13(6):e0198582. doi: 10.1371/journal.pone.0198582

3. Wheatley LM, Plaut M, Schwaninger JM, Banerji A, Castells M, Finkelman FD, et al. Report From the National Institute of Allergy and Infectious Diseases Workshop on Drug Allergy. J Allergy Clin Immunol (2015) 136 (2):262-71.e2. doi: 10.1016/j.jaci.2015.05.027

4. Patel S, John AM, Handler MZ, Schwartz RA. Fixed Drug Eruptions: An Update, Emphasizing the Potentially Lethal Generalized Bullous Fixed Drug Eruption. Am J Clin Dermatol (2020) 21(3):393-9. doi: 10.1007/s40257-020-00505-3

5. Lipowicz S, Sekula P, Ingen-Housz-Oro S, Liss Y, Sassolas B, Dunant A, et al. Prognosis of Generalized Bullous Fixed Drug Eruption: Comparison With Stevens-Johnson Syndrome and Toxic Epidermal Necrolysis. Br J Dermatol (2013) 168(4):726-32. doi: 10.1111/bjd.12133

6. Clark RA. Resident Memory T Cells in Human Health and Disease. Sci Transl Med (2015) 7(269):269rv1. doi: 10.1126/scitranslmed.3010641

7. Schenkel JM, Masopust D. Tissue-Resident Memory T Cells. Immunity (2014) 41(6):886-97. doi: 10.1016/j.immuni.2014.12.007

8. Park CO, Kupper TS. The Emerging Role of Resident Memory T Cells in Protective Immunity and Inflammatory Disease. Nat Med (2015) 21(7):68897. doi: $10.1038 / \mathrm{nm} .3883$

9. Budd RC, Cerottini JC, Horvath C, Bron C, Pedrazzini T, Howe RC, et al. Distinction of Virgin and Memory T Lymphocytes. Stable Acquisition of the Pgp-1 Glycoprotein Concomitant With Antigenic Stimulation. J Immunol (1987) 138(10):3120-9.

10. Croft M, Duncan DD, Swain SL. Response of Naive Antigen-Specific CD4+ T Cells In Vitro: Characteristics and Antigen-Presenting Cell Requirements. J Exp Med (1992) 176(5):1431-7. doi: 10.1084/jem.176.5.1431

11. Cebrian M, Yague E, Rincon M, Lopez-Botet M, de Landazuri MO, SanchezMadrid F. Triggering of T Cell Proliferation Through AIM, an Activation Inducer Molecule Expressed on Activated Human Lymphocytes. J Exp Med (1988) 168(5):1621-37. doi: 10.1084/jem.168.5.1621

12. Testi R, Phillips JH, Lanier LL. Leu 23 Induction as an Early Marker of Functional CD3/T Cell Antigen Receptor Triggering. Requirement for Receptor Cross-Linking, Prolonged Elevation of Intracellular [Ca++] and Stimulation of Protein Kinase C. J Immunol (1989) 142(6):1854-60.

13. Lambrecht BN, Pauwels RA, Fazekas De St Groth B. Induction of Rapid T Cell Activation, Division, and Recirculation by Intratracheal Injection of Dendritic Cells in a TCR Transgenic Model. J Immunol (2000) 164(6):2937-46. doi: 10.4049/jimmunol.164.6.2937

14. Nolz JC, Starbeck-Miller GR, Harty JT. Naive, Effector and Memory CD8 TCell Trafficking: Parallels and Distinctions. Immunotherapy (2011) 3 (10):1223-33. doi: 10.2217/imt.11.100

15. Golubovskaya V, Wu L. Different Subsets of T Cells, Memory, Effector Functions, and CAR-T Immunotherapy. Cancers (Basel) (2016) 8(3):36. doi: $10.3390 /$ cancers 8030036

16. Martin MD, Badovinac VP. Defining Memory CD8 T Cell. Front Immunol (2018) 9:2692. doi: 10.3389/fimmu.2018.02692

17. Akbar AN, Terry L, Timms A, Beverley PC, Janossy G. Loss of CD45R and Gain of UCHL1 Reactivity Is a Feature of Primed T Cells. J Immunol (1988) 140(7):2171-8.

\section{FUNDING}

This work was funded by the National Institutes of Health DP5 OD023091 and R21 AI150657 (SD) the German Research Foundation, DFG Project number: 423175926, GZ: SCHU 3377/1-1 (ES) and the Sun Pharma/SID Innovation Research Fellowship (PS).

18. Sallusto F, Lenig D, Forster R, Lipp M, Lanzavecchia A. Two Subsets of Memory T Lymphocytes With Distinct Homing Potentials and Effector Functions. Nature (1999) 401(6754):708-12. doi: 10.1038/44385

19. Clark RA, Chong BF, Mirchandani N, Yamanaka K, Murphy GF, Dowgiert RK, et al. A Novel Method for the Isolation of Skin Resident T Cells From Normal and Diseased Human Skin. J Invest Dermatol (2006) 126(5):1059-70. doi: $10.1038 /$ sj.jid.5700199

20. Sathaliyawala T, Kubota M, Yudanin N, Turner D, Camp P, Thome JJ, et al. Distribution and Compartmentalization of Human Circulating and TissueResident Memory T Cell Subsets. Immunity (2013) 38(1):187-97. doi: 10.1016/j.immuni.2012.09.020

21. Purwar R, Campbell J, Murphy G, Richards WG, Clark RA, Kupper TS Resident Memory T Cells (T(RM)) Are Abundant in Human Lung: Diversity, Function, and Antigen Specificity. PloS One (2011) 6(1):e16245. doi: 10.1371/ journal.pone.0016245

22. Clark RA, Chong B, Mirchandani N, Brinster NK, Yamanaka K, Dowgiert RK, et al. The Vast Majority of CLA+ T Cells Are Resident in Normal Skin. J Immunol (2006) 176(7):4431-9. doi: 10.4049/jimmunol.176.7.4431

23. Pallett LJ, Davies J, Colbeck EJ, Robertson F, Hansi N, Easom NJW, et al. IL-2 (High) Tissue-Resident T Cells in the Human Liver: Sentinels for Hepatotropic Infection. J Exp Med (2017) 214(6):1567-80. doi: 10.1084/jem.20162115

24. Stelma F, de Niet A, Sinnige MJ, van Dort KA, van Gisbergen K, Verheij J, et al. Human Intrahepatic CD69 + CD8+ T Cells Have a Tissue Resident Memory T Cell Phenotype With Reduced Cytolytic Capacity. Sci Rep (2017) 7 (1):6172. doi: 10.1038/s41598-017-06352-3

25. Bromley SK, Thomas SY, Luster AD. Chemokine Receptor CCR7 Guides T Cell Exit From Peripheral Tissues and Entry Into Afferent Lymphatics. Nat Immunol (2005) 6(9):895-901. doi: 10.1038/ni1240

26. Bai A, Hu H, Yeung M, Chen J. Kruppel-Like Factor 2 Controls T Cell Trafficking by Activating L-Selectin (CD62L) and Sphingosine-1-Phosphate Receptor 1 Transcription. J Immunol (2007) 178(12):7632-9. doi: 10.4049/ jimmunol.178.12.7632

27. Skon CN, Lee JY, Anderson KG, Masopust D, Hogquist KA, Jameson SC. Transcriptional Downregulation of S1pr1 Is Required for the Establishment of Resident Memory CD8+ T Cells. Nat Immunol (2013) 14(12):1285-93. doi: 10.1038/ni.2745

28. Mackay LK, Braun A, Macleod BL, Collins N, Tebartz C, Bedoui S, et al. Cutting Edge: CD69 Interference With Sphingosine-1-Phosphate Receptor Function Regulates Peripheral T Cell Retention. J Immunol (2015) 194 (5):2059-63. doi: 10.4049/jimmunol.1402256

29. Watanabe R, Gehad A, Yang C, Scott LL, Teague JE, Schlapbach C, et al. Human Skin Is Protected by Four Functionally and Phenotypically Discrete Populations of Resident and Recirculating Memory T Cells. Sci Transl Med (2015) 7(279):279ra39. doi: 10.1126/scitranslmed.3010302

30. Mackay LK, Rahimpour A, Ma JZ, Collins N, Stock AT, Hafon ML, et al. The Developmental Pathway for CD103(+)CD8+ Tissue-Resident Memory T Cells of Skin. Nat Immunol (2013) 14(12):1294-301. doi: 10.1038/ni.2744

31. Zhang N, Bevan MJ. Transforming Growth Factor-Beta Signaling Controls the Formation and Maintenance of Gut-Resident Memory $\mathrm{T}$ Cells by Regulating Migration and Retention. Immunity (2013) 39(4):687-96. doi: 10.1016/j.immuni.2013.08.019

32. Cepek KL, Shaw SK, Parker CM, Russell GJ, Morrow JS, Rimm DL, et al. Adhesion Between Epithelial Cells and T Lymphocytes Mediated by ECadherin and the Alpha E Beta 7 Integrin. Nature (1994) 372(6502):190-3. doi: $10.1038 / 372190 \mathrm{a} 0$

33. McCully ML, Ladell K, Andrews R, Jones RE, Miners KL, Roger L, et al. CCR8 Expression Defines Tissue-Resident Memory $\mathrm{T}$ Cells in Human Skin. J Immunol (2018) 200(5):1639-50. doi: 10.4049/jimmunol.1701377 
34. Schaerli P, Ebert L, Willimann K, Blaser A, Roos RS, Loetscher P, et al. A SkinSelective Homing Mechanism for Human Immune Surveillance T Cells. J Exp Med (2004) 199(9):1265-75. doi: 10.1084/jem.20032177

35. McCully ML, Ladell K, Hakobyan S, Mansel RE, Price DA, Moser B. Epidermis Instructs Skin Homing Receptor Expression in Human T Cells. Blood (2012) 120(23):4591-8. doi: 10.1182/blood-2012-05-433037

36. Xia M, Hu S, Fu Y, Jin W, Yi Q, Matsui Y, et al. CCR10 Regulates Balanced Maintenance and Function of Resident Regulatory and Effector T Cells to Promote Immune Homeostasis in the Skin. J Allergy Clin Immunol (2014) 134 (3):634-44.e10. doi: 10.1016/j.jaci.2014.03.010

37. Zaid A, Hor JL, Christo SN, Groom JR, Heath WR, Mackay LK, et al. Chemokine Receptor-Dependent Control of Skin Tissue-Resident Memory T Cell Formation. J Immunol (2017) 199(7):2451-9. doi: 10.4049/jimmunol.1700571

38. Liu L, Zhong Q, Tian T, Dubin K, Athale SK, Kupper TS. Epidermal Injury and Infection During Poxvirus Immunization Is Crucial for the Generation of Highly Protective T Cell-Mediated Immunity. Nat Med (2010) 16(2):224-7. doi: 10.1038/nm.2078

39. Jiang X, Clark RA, Liu L, Wagers AJ, Fuhlbrigge RC, Kupper TS. Skin Infection Generates Non-Migratory Memory CD8+ T(RM) Cells Providing Global Skin Immunity. Nature (2012) 483(7388):227-31. doi: 10.1038/ nature10851

40. Gebhardt T, Wakim LM, Eidsmo L, Reading PC, Heath WR, Carbone FR. Memory T Cells in Nonlymphoid Tissue That Provide Enhanced Local Immunity During Infection With Herpes Simplex Virus. Nat Immunol (2009) 10(5):524-30. doi: 10.1038/ni.1718

41. Mackay LK, Stock AT, Ma JZ, Jones CM, Kent SJ, Mueller SN, et al. LongLived Epithelial Immunity by Tissue-Resident Memory T (TRM) Cells in the Absence of Persisting Local Antigen Presentation. Proc Natl Acad Sci USA (2012) 109(18):7037-42. doi: 10.1073/pnas.1202288109

42. Clark RA, Watanabe R, Teague JE, Schlapbach C, Tawa MC, Adams N, et al. Skin Effector Memory T Cells do Not Recirculate and Provide Immune Protection in Alemtuzumab-Treated CTCL Patients. Sci Trans Med (2012) 4 (117):117ra7. doi: 10.1126/scitranslmed.3003008

43. Dijkgraaf FE, Matos TR, Hoogenboezem M, Toebes M, Vredevoogd DW, Mertz M, et al. Tissue Patrol by Resident Memory CD8(+) T Cells in Human Skin. Nat Immunol (2019) 20(6):756-64. doi: 10.1038/s41590-019-0404-3

44. Ariotti S, Beltman JB, Chodaczek G, Hoekstra ME, van Beek AE, GomezEerland R, et al. Tissue-Resident Memory CD8+ T Cells Continuously Patrol Skin Epithelia to Quickly Recognize Local Antigen. Proc Natl Acad Sci USA (2012) 109(48):19739-44. doi: 10.1073/pnas.1208927109

45. Seidel JA, Vukmanovic-Stejic M, Muller-Durovic B, Patel N, Fuentes-Duculan J, Henson SM, et al. Skin Resident Memory CD8(+) T Cells Are Phenotypically and Functionally Distinct From Circulating Populations and Lack Immediate Cytotoxic Function. Clin Exp Immunol (2018) 194(1):79-92. doi: 10.1111/ cei.13189

46. Cheuk S, Schlums H, Gallais Serezal I, Martini E, Chiang SC, Marquardt N, et al. CD49a Expression Defines Tissue-Resident CD8(+) T Cells Poised for Cytotoxic Function in Human Skin. Immunity (2017) 46(2):287-300. doi: 10.1016/j.immuni.2017.01.009

47. Bromley SK, Akbaba H, Mani V, Mora-Buch R, Chasse AY, Sama A, et al. CD49a Regulates Cutaneous Resident Memory CD8(+) T Cell Persistence and Response. Cell Rep (2020) 32(9):108085. doi: 10.1016/j.celrep.2020.108085

48. Davies B, Prier JE, Jones CM, Gebhardt T, Carbone FR, Mackay LK. Cutting Edge: Tissue-Resident Memory T Cells Generated by Multiple Immunizations or Localized Deposition Provide Enhanced Immunity. J Immunol (2017) 198 (6):2233-7. doi: 10.4049/jimmunol.1601367

49. Gaide O, Emerson RO, Jiang X, Gulati N, Nizza S, Desmarais C, et al. Common Clonal Origin of Central and Resident Memory T Cells Following Skin Immunization. Nat Med (2015) 21(6):647-53. doi: 10.1038/nm.3860

50. Brunner PM, Emerson RO, Tipton C, Garcet S, Khattri S, Coats I, et al. Nonlesional Atopic Dermatitis Skin Shares Similar T-Cell Clones With Lesional Tissues. Allergy (2017) 72(12):2017-25. doi: 10.1111/all.13223

51. Matos TR, O'Malley JT, Lowry EL, Hamm D, Kirsch IR, Robins HS, et al. Clinically Resolved Psoriatic Lesions Contain Psoriasis-Specific IL-17Producing Alphabeta T Cell Clones. J Clin Invest (2017) 127(11):4031-41. doi: 10.1172/JCI93396

52. Gallais Serezal I, Classon C, Cheuk S, Barrientos-Somarribas M, Wadman E, Martini E, et al. Resident T Cells in Resolved Psoriasis Steer Tissue Responses
That Stratify Clinical Outcome. J Invest Dermatol (2018) 138(8):1754-63. doi: 10.1016/j.jid.2018.02.030

53. Gallais Serezal I, Hoffer E, Ignatov B, Martini E, Zitti B, Ehrstrom M, et al. A Skewed Pool of Resident T Cells Triggers Psoriasis-Associated Tissue Responses in Never-Lesional Skin From Patients With Psoriasis. J Allergy Clin Immunol (2019) 143(4):1444-54. doi: 10.1016/j.jaci.2018.08.048

54. Divito SJ, Aasebo AT, Matos TR, Hsieh PC, Collin M, Elco CP, et al. Peripheral Host T Cells Survive Hematopoietic Stem Cell Transplantation and Promote Graft-Versus-Host Disease. J Clin Invest (2020) 130(9):4624-36. doi: $10.1172 / J C I 129965$

55. Gadsboll AO, Jee MH, Funch AB, Alhede M, Mraz V, Weber JF, et al. Pathogenic CD8(+) Epidermis-Resident Memory T Cells Displace Dendritic Epidermal T Cells in Allergic Dermatitis. J Invest Dermatol (2020) 140 (4):806-15.e5. doi: 10.1016/j.jid.2019.07.722

56. Gamradt P, Laoubi L, Nosbaum A, Mutez V, Lenief V, Grande S, et al. Inhibitory Checkpoint Receptors Control CD8(+) Resident Memory T Cells to Prevent Skin Allergy. J Allergy Clin Immunol (2019) 143(6):2147-57.e9. doi: 10.1016/j.jaci.2018.11.048

57. Posadas SJ, Padial A, Torres MJ, Mayorga C, Leyva L, Sanchez E, et al. Delayed Reactions to Drugs Show Levels of Perforin, Granzyme B, and Fas-L to be Related to Disease Severity. J Allergy Clin Immunol (2002) 109(1):155-61. doi: 10.1067/mai.2002.120563

58. Chung WH, Hung SI, Yang JY, Su SC, Huang SP, Wei CY, et al. Granulysin Is a Key Mediator for Disseminated Keratinocyte Death in Stevens-Johnson Syndrome and Toxic Epidermal Necrolysis. Nat Med (2008) 14(12):1343-50. doi: $10.1038 / \mathrm{nm} .1884$

59. Ko TM, Chung WH, Wei CY, Shih HY, Chen JK, Lin CH, et al. Shared and Restricted T-Cell Receptor Use Is Crucial for Carbamazepine-Induced Stevens-Johnson Syndrome. J Allergy Clin Immunol (2011) 128(6):126676.e11. doi: 10.1016/j.jaci.2011.08.013

60. Keane NM, Pavlos RK, McKinnon E, Lucas A, Rive C, Blyth CC, et al. HLA Class I Restricted CD8+ and Class II Restricted CD4+ T Cells Are Implicated in the Pathogenesis of Nevirapine Hypersensitivity. AIDS (2014) 28(13):1891901. doi: 10.1097/QAD.0000000000000345

61. Sousa-Pinto B, Correia C, Gomes L, Gil-Mata S, Araujo L, Correia O, et al. HLA and Delayed Drug-Induced Hypersensitivity. Int Arch Allergy Immunol (2016) 170(3):163-79. doi: 10.1159/000448217

62. Sukasem C, Katsila T, Tempark T, Patrinos GP, Chantratita W. Drug-Induced Stevens-Johnson Syndrome and Toxic Epidermal Necrolysis Call for Optimum Patient Stratification and Theranostics via Pharmacogenomics. Annu Rev Genomics Hum Genet (2018) 19:329-53. doi: 10.1146/annurev-genom-083115-022324

63. Cheng CY, Su SC, Chen CH, Chen WL, Deng ST, Chung WH. HLA Associations and Clinical Implications in T-Cell Mediated Drug Hypersensitivity Reactions: An Updated Review. J Immunol Res (2014) 2014:565320. doi: 10.1155/2014/565320

64. Mallal S, Nolan D, Witt C, Masel G, Martin AM, Moore C, et al. Association Between Presence of HLA-B ${ }^{\star 5701}$, HLA-DR7, and HLA-DQ3 and Hypersensitivity to HIV-1 Reverse-Transcriptase Inhibitor Abacavir. Lancet (2002) 359(9308):727-32. doi: 10.1016/S0140-6736(02)07873-X

65. Chung WH, Hung SI, Hong HS, Hsih MS, Yang LC, Ho HC, et al. Medical Genetics: A Marker for Stevens-Johnson Syndrome. Nature (2004) 428(6982):486. doi: $10.1038 / 428486 a$

66. Bellon T. Mechanisms of Severe Cutaneous Adverse Reactions: Recent Advances. Drug Saf (2019) 42(8):973-92. doi: 10.1007/s40264-019-00825-2

67. Iriki H, Adachi T, Mori M, Tanese K, Funakoshi T, Karigane D, et al. Toxic Epidermal Necrolysis in the Absence of Circulating T Cells: A Possible Role for Resident Memory T Cells. J Am Acad Dermatol (2014) 71(5):e214-6. doi: 10.1016/j.jaad.2014.07.013

68. Trubiano JA, Gordon CL, Castellucci C, Christo SN, Park SL, Mouhtouris E, et al. Analysis of Skin-Resident Memory T Cells Following Drug Hypersensitivity Reactions. J Invest Dermatol (2019) 140(7):1442-5.e4. doi: 10.1016/ j.jid.2019.11.020

69. Mallal S, Phillips E, Carosi G, Molina JM, Workman C, Tomazic J, et al. HLAB 5701 Screening for Hypersensitivity to Abacavir. N Engl J Med (2008) 358 (6):568-79. doi: 10.1056/NEJMoa0706135

70. Schnyder B, Adam J, Rauch A, Thurnheer MC, Pichler WJ. HLA-B ${ }^{\star} 57: 01(+)$ Abacavir-Naive Individuals Have Specific T Cells But No Patch Test Reactivity. J Allergy Clin Immunol (2013) 132(3):756-8. doi: 10.1016/j.jaci.2013.04.013 
71. Hassoun-Kheir N, Bergman R, Weltfriend S. The Use of Patch Tests in the Diagnosis of Delayed Hypersensitivity Drug Eruptions. Int J Dermatol (2016) 55(11):1219-24. doi: 10.1111/ijd.13306

72. Barbaud A, Reichert-Penetrat S, Trechot P, Jacquin-Petit MA, Ehlinger A, Noirez V, et al. The Use of Skin Testing in the Investigation of Cutaneous Adverse Drug Reactions. Br J Dermatol (1998) 139(1):49-58. doi: 10.1046/ j.1365-2133.1998.02313.x

73. Osawa J, Naito S, Aihara M, Kitamura K, Ikezawa Z, Nakajima H. Evaluation of Skin Test Reactions in Patients With Non-Immediate Type Drug Eruptions. J Dermatol (1990) 17(4):235-9. doi: 10.1111/j.1346-8138.1990.tb01631.x

74. Hsu YO, Lu KL, Fu Y, Wang CW, Lu CW, Lin YF, et al. The Roles of Immunoregulatory Networks in Severe Drug Hypersensitivity. Front Immunol (2021) 12:597761. doi: 10.3389/fimmu.2021.597761

75. Goldinger SM, Stieger P, Meier B, Micaletto S, Contassot E, French LE, et al. Cytotoxic Cutaneous Adverse Drug Reactions During Anti-PD-1 Therapy. Clin Cancer Res (2016) 22(16):4023-9. doi: 10.1158/1078-0432.CCR-15-2872

76. Raschi E, Antonazzo IC, La Placa M, Ardizzoni A, Poluzzi E, De Ponti F. Serious Cutaneous Toxicities With Immune Checkpoint Inhibitors in the U.S. Food and Drug Administration Adverse Event Reporting System. Oncologist (2019) 24(11):e1228-31. doi: 10.1634/theoncologist.2019-0250

77. Mizukawa Y, Yamazaki Y, Teraki Y, Hayakawa J, Hayakawa K, Nuriya H, et al. Direct Evidence for Interferon-Gamma Production by Effector-MemoryType Intraepidermal T Cells Residing at an Effector Site of Immunopathology in Fixed Drug Eruption. Am J Pathol (2002) 161(4):1337-47. doi: 10.1016/ S0002-9440(10)64410-0

78. Sallusto F, Geginat J, Lanzavecchia A. Central Memory and Effector Memory T Cell Subsets: Function, Generation, and Maintenance. Annu Rev Immunol (2004) 22:745-63. doi: 10.1146/annurev.immunol.22.012703.104702

79. Tian Y, Babor M, Lane J, Schulten V, Patil VS, Seumois G, et al. Unique Phenotypes and Clonal Expansions of Human CD4 Effector Memory T Cells Re-Expressing CD45RA. Nat Commun (2017) 8(1):1473. doi: 10.1038/s41467017-01728-5

80. Pavlos R, White KD, Wanjalla C, Mallal SA, Phillips EJ. Severe Delayed Drug Reactions: Role of Genetics and Viral Infections. Immunol Allergy Clin North Am (2017) 37(4):785-815. doi: 10.1016/j.iac.2017.07.007

81. Picard D, Janela B, Descamps V, D'Incan M, Courville P, Jacquot S, et al. Drug Reaction With Eosinophilia and Systemic Symptoms (DRESS): A Multiorgan Antiviral T Cell Response. Sci Transl Med (2010) 2(46):46ra62. doi: 10.1126/ scitranslmed.3001116

82. Ushigome Y, Kano Y, Ishida T, Hirahara K, Shiohara T. Short- and LongTerm Outcomes of 34 Patients With Drug-Induced Hypersensitivity Syndrome in a Single Institution. J Am Acad Dermatol (2013) 68(5):721-8. doi: 10.1016/j.jaad.2012.10.017

83. Seishima M, Yamanaka S, Fujisawa T, Tohyama M, Hashimoto K. Reactivation of Human Herpesvirus (HHV) Family Members Other Than HHV-6 in Drug-Induced Hypersensitivity Syndrome. Br J Dermatol (2006) 155(2):344-9. doi: 10.1111/j.1365-2133.2006.07332.x

84. Onodi-Nagy K, Kinyo A, Meszes A, Garaczi E, Kemeny L, Bata-Csorgo Z. Amoxicillin Rash in Patients With Infectious Mononucleosis: Evidence of True Drug Sensitization. Allergy Asthma Clin Immunol (2015) 11(1):1. doi: 10.1186/1710-1492-11-1

85. Teraki Y, Murota H, Izaki S. Toxic Epidermal Necrolysis Due to Zonisamide Associated With Reactivation of Human Herpesvirus 6. Arch Dermatol (2008) 144(2):232-5. doi: 10.1001/archdermatol.2007.48

86. Ishida T, Kano Y, Mizukawa Y, Shiohara T. The Dynamics of Herpesvirus Reactivations During and After Severe Drug Eruptions: Their Relation to the Clinical Phenotype and Therapeutic Outcome. Allergy (2014) 69(6):798-805. doi: $10.1111 /$ all.12410

87. Chung WH, Chang WC, Stocker SL, Juo CG, Graham GG, Lee MH, et al. Insights Into the Poor Prognosis of Allopurinol-Induced Severe Cutaneous Adverse Reactions: The Impact of Renal Insufficiency, High Plasma Levels of
Oxypurinol and Granulysin. Ann Rheum Dis (2015) 74(12):2157-64. doi: 10.1136/annrheumdis-2014-205577

88. Ng CY, Yeh YT, Wang CW, Hung SI, Yang CH, Chang YC, et al. Impact of the HLA-B $\left.{ }^{*}\right)$ 58:01 Allele and Renal Impairment on Allopurinol-Induced Cutaneous Adverse Reactions. J Invest Dermatol (2016) 136(7):1373-81. doi: $10.1016 /$ j.jid.2016.02.808

89. Almeida CA, van Miert P, O'Driscoll K, Zoet YM, Chopra A, Witt C, et al. Virus-Specific T-Cell Clonotypes Might Contribute to Drug Hypersensitivity Reactions Through Heterologous Immunity. J Allergy Clin Immunol (2019) 144(2):608-11.e4. doi: 10.1016/j.jaci.2019.05.009

90. Pan Y, Liu L, Tian T, Zhao J, Park CO, Lofftus SY, et al. Epicutaneous Immunization With Modified Vaccinia Ankara Viral Vectors Generates Superior T Cell Immunity Against a Respiratory Viral Challenge. NPJ Vaccines (2021) 6(1):1. doi: 10.1038/s41541-020-00265-5

91. Lucas A, Lucas M, Strhyn A, Keane NM, McKinnon E, Pavlos R, et al. Abacavir-Reactive Memory T Cells Are Present in Drug Naive Individuals. PloS One (2015) 10(2):e0117160. doi: 10.1371/journal.pone.0117160

92. Abuzakouk M, Feighery C, O'Farrelly C. Collagenase and Dispase Enzymes Disrupt Lymphocyte Surface Molecules. J Immunol Methods (1996) 194 (2):211-6. doi: 10.1016/0022-1759(96)00038-5

93. Autengruber A, Gereke M, Hansen G, Hennig C, Bruder D. Impact of Enzymatic Tissue Disintegration on the Level of Surface Molecule Expression and Immune Cell Function. Eur J Microbiol Immunol (Bp) (2012) 2(2):112-20. doi: 10.1556/EuJMI.2.2012.2.3

94. Botting RA, Bertram KM, Baharlou H, Sandgren KJ, Fletcher J, Rhodes JW, et al. Phenotypic and Functional Consequences of Different Isolation Protocols on Skin Mononuclear Phagocytes. J Leukoc Biol (2017) 101 (6):1393-403. doi: 10.1189/jlb.4A1116-496R

95. Gattinoni L, Lugli E, Ji Y, Pos Z, Paulos CM, Quigley MF, et al. A Human Memory T Cell Subset With Stem Cell-Like Properties. Nat Med (2011) 17 (10):1290-7. doi: 10.1038/nm.2446

96. Klicznik MM, Morawski PA, Hollbacher B, Varkhande SR, Motley SJ, KuriCervantes L, et al. Human CD4(+)CD103(+) Cutaneous Resident Memory T Cells Are Found in the Circulation of Healthy Individuals. Sci Immunol (2019) 4(37):eaav8995. doi: 10.1126/sciimmunol.aav8995

97. Buggert M, Vella LA, Nguyen S, Wu VH, Chen Z, Sekine T, et al. The Identity of Human Tissue-Emigrant CD8(+) T Cells. Cell (2020) 183(7):1946-61.e15. doi: $10.1101 / 2020.08 .11 .236372$

98. Cardone M, Garcia K, Tilahun ME, Boyd LF, Gebreyohannes S, Yano M, et al. A Transgenic Mouse Model for HLA-B`57:01-Linked Abacavir Drug Tolerance and Reactivity. J Clin Invest (2018) 128(7):2819-32. doi: 10.1172/JCI99321

99. Pan RY, Chu MT, Wang CW, Lee YS, Lemonnier F, Michels AW, et al. Identification of Drug-Specific Public TCR Driving Severe Cutaneous Adverse Reactions. Nat Commun (2019) 10(1):3569. doi: 10.1038/s41467-019-11396-2

Conflict of Interest: The authors declare that the research was conducted in the absence of any commercial or financial relationships that could be construed as a potential conflict of interest.

Publisher's Note: All claims expressed in this article are solely those of the authors and do not necessarily represent those of their affiliated organizations, or those of the publisher, the editors and the reviewers. Any product that may be evaluated in this article, or claim that may be made by its manufacturer, is not guaranteed or endorsed by the publisher.

Copyright ( $\odot 2021$ Schunkert, Shah and Divito. This is an open-access article distributed under the terms of the Creative Commons Attribution License (CC BY). The use, distribution or reproduction in other forums is permitted, provided the original author(s) and the copyright owner(s) are credited and that the original publication in this journal is cited, in accordance with accepted academic practice. No use, distribution or reproduction is permitted which does not comply with these terms. 